\title{
KAPASITAS LENTUR BALOK KOMPOSIT BETON DENGAN BAJA RINGAN
}

\author{
Yuyu OKTARINATA ${ }^{1 *}$, Indra GUNAWAN ${ }^{2}$, Donny FRANSISKUS MANALU ${ }^{3}$ \\ ${ }^{1}$ Jurusan Teknik Sipil, Fakultas Teknik, Universitas Bangka Belitung, Bangka, Indonesia \\ ${ }^{2} J u r u s a n$ Teknik Sipil, Fakultas Teknik, Universitas Bangka Belitung, Bangka, Indonesia \\ ${ }^{3}$ Jurusan Teknik Sipil, Fakultas Teknik, Universitas Bangka Belitung, Bangka, Indonesia \\ *Email korespondensi: yuyuoktarinata910@gmail.com
}

[diterima: 30 Oktober 2020, disetujui: 30 Desember 2020]

\begin{abstract}
The application of mild steel construction is commonly used as roof truss for building. To develop the used of mild steel in construction, an experimental study is carried out to investigate the application of mild steel as reinforcement for reinforced concrete beam. Reinforced concrete beams are designed to 17 MPa which is burdened with 2 points of loading. The test object consist of 4 variations; Variation A is beam with conventional reinforcement (doubly), Variation B is beam with mild steel reinforcement (doubly), Variation C is beam with mild steel reinforcement (singly), and Variation D is combination of conventional - compression reinforcement and mild steel - tensile reinforcement. Based on theoritical analysis, bending moment values for Variation $\mathrm{A}=3,726 \mathrm{kN}-\mathrm{m}, \mathrm{B}=5,460 \mathrm{kN}-\mathrm{m}, \mathrm{C}=5,460 \mathrm{kN}-\mathrm{m}$, and $\mathrm{D}=6,780 \mathrm{kN}-\mathrm{m} ; \mathrm{kNm}$; deflection values for Variation $\mathrm{A}=0,791 \mathrm{~mm}, \mathrm{~B}=0,575 \mathrm{~mm}, \mathrm{C}=0,532 \mathrm{~mm}$, and $\mathrm{D}=0,655 \mathrm{~mm}$. Based on experimental results, flexure strength values for Variation $\mathrm{A}=16,313 \mathrm{MPa}$, $\mathrm{C}=10,679 \mathrm{MPa}$, and $\mathrm{D}=13,309 \mathrm{MPa}$; bending moment values for Variation $\mathrm{A}=13,199 \mathrm{kN}-\mathrm{m}, \mathrm{B}=$ $9,561 \mathrm{kN}-\mathrm{m}, \mathrm{C}=8,913 \mathrm{kN}-\mathrm{m}$, dan $\mathrm{D}=11,248 \mathrm{kN}-\mathrm{m}$; deflection values for Variation $\mathrm{A}=2,173 \mathrm{~mm}, \mathrm{~B}=$ $2,420 \mathrm{~mm}, \mathrm{C}=2,187 \mathrm{~mm}$, and $\mathrm{D}=2,420 \mathrm{~mm}$. The results can be concluded that Variation A-Beam has a greater value of flexural strength and bending moment with smaller deflection compared to Variation $\mathrm{B}$, $\mathrm{C}$ and $\mathrm{D}$ beams.
\end{abstract}

Key words: Mild steel, beam, flexural

\section{INTISARI}

Penggunaan baja ringan dalam dunia konstruksi sering digunakan sebagai rangka atap pada bangunan. Untuk mengembangkan penggunaan baja ringan dalam dunia konstruksi, maka dilakukan penelitian tentang penggunaan baja ringan sebagai tulangan pada balok beton bertulang. Penelitian ini dilakukan dengan pengujian kuat lentur pada balok beton bertulang dengan mutu beton $17 \mathrm{MPa}$ yang dibebani 2 titik pembebanan. Benda uji terdiri dari 4 variasi; dimana variasi A adalah balok dengan tulangan baja konvensional (rangkap), variasi B adalah balok dengan tulangan baja ringan (rangkap), variasi C adalah balok dengan tulangan baja ringan (tunggal), dan variasi $\mathrm{D}$ adalah kombinasi tulangan baja konvensional di daerah tekan dan baja ringan di daerah tarik. Berdasarkan analisis teoritis, nilai momen lentur untuk variasi $\mathrm{A}=3,726 \mathrm{kNm}, \mathrm{B}=5,460 \mathrm{kNm}, \mathrm{C}=5,460 \mathrm{kNm}$, dan $\mathrm{D}=6,780 \mathrm{kNm}$; nilai lendutan untuk variasi $A=0,791 \mathrm{~mm}, \mathrm{~B}=0,575 \mathrm{~mm}, \mathrm{C}=0,532 \mathrm{~mm}$, dan $\mathrm{D}=0,655 \mathrm{~mm}$. Berdasarkan hasil pengujian, nilai kuat lentur untuk variasi $\mathrm{A}=16,313 \mathrm{MPa}, \mathrm{C}=10,679 \mathrm{MPa}$, dan $\mathrm{D}=13,309 \mathrm{MPa}$; nilai momen lentur untuk variasi $\mathrm{A}=13,199 \mathrm{kNm}, \mathrm{B}=9,561 \mathrm{kNm}, \mathrm{C}=8,913 \mathrm{kNm}$, dan $\mathrm{D}=11,248 \mathrm{kNm}$; nilai lendutan untuk variasi $\mathrm{A}=2,173 \mathrm{~mm}, \mathrm{~B}=2,420 \mathrm{~mm}, \mathrm{C}=2,187 \mathrm{~mm}$, dan $\mathrm{D}=2,420 \mathrm{~mm}$. Dengan demikian dapat disimpulkan bahwa balok variasi A memiliki nilai kuat lentur dan momen lentur yang lebih besar dengan nilai lendutan yang lebih kecil dibandingkan dengan balok variasi B, C, dan D.

Kata kunci: Baja ringan, balok, lentur 


\section{PENDAHULUAN}

\section{Latar Belakang}

Beton bertulang merupakan kombinasi antara material beton dengan tulangan baja yang digabungkan menjadi satu kesatuan untuk memikul beban yang bekerja. Menurut Setiawan (2016), pada suatu balok beton bertulang, gaya tarik yang timbul sebagai akibat dari momen lentur ditahan oleh tulangan baja, sedangkan beton sendiri bekerja menahan gaya tekan yang timbul. Selain itu, dengan adanya tulangan baja dapat mengubah sifat beton yang semula getas menjadi ductile. Tulangan baja yang sering digunakan ada dua jenis, yakni polos dan ulir. Tulangan baja memiliki tegangan leleh minimum $\left(f_{\mathrm{y}}\right)$ berkisar dari $210 \mathrm{MPa}-410 \mathrm{MPa}$

Selain tulangan baja, saat ini terdapat baja ringan yang umumnya digunakan sebagai rangka atap di bidang konstruksi. Baja ringan merupakan jenis baja yang dibentuk setelah dingin, dengan mutu tinggi yang bersifat ringan dan tipis. Baja ringan memiliki mutu baja G550, yang berarti baja memiliki kuat tarik $550 \mathrm{MPa}$. Berdasarkan Dekoruma (2018), salah satu merk baja ringan yang sangat populer di pasaran adalah baja ringan TASO. Salah satu model baja ringan TASO berbentuk "Canal" atau "C". Model ini merupakan produk baja ringan TASO yang paling umum digunakan, karena baja ringan TASO juga telah banyak dijumpai di pasaran. Kelebihan dari baja ringan TASO model " $\mathrm{C}$ " ini adalah pada saat digabungkan dua batang baja ringan yang saling berhadapan dan dapat disatukan menjadi bentuk kotak, sehingga memperkuat rangka satu sama lain. Hal inilah yang menjadi dasar peneliti dalam melakukan penelitian penggunaan baja ringan pada elemen struktur seperti pengganti tulangan pada balok beton bertulang.

Oleh karena itu, pada penelitian ini peneliti menggunakan baja ringan TASO model "C" dengan ukuran $35 \times 75 \times 0,75 \mathrm{~mm}$ untuk dijadikan sebagai tulangan pada balok beton bertulang. Pemilihan profil baja ringan dengan dimensi tersebut dikarenakan mudah didapatkan dipasaran. Dalam penelitian ini, peneliti akan meninjau kemampuan balok dari nilai kapasitas lentur balok. Kapasitas lentur pada balok adalah tingkat kemampuan maksimum dari balok dalam menerima gaya luar yang bekerja pada struktur balok dengan batas lendutan yang diizinkan. Untuk pengujian kuat lentur pada balok terdapat 12 sampel benda uji dengan 4 variasi, dimana variasi $\mathrm{A}$ adalah balok dengan tulangan baja konvensional, variasi $\mathrm{B}$ adalah balok dengan tulangan baja ringan profil $\mathrm{C}$ di bagian tekan dan tarik, variasi $\mathrm{C}$ adalah balok dengan tulangan baja ringan profil $\mathrm{C}$ di bagian tarik, dan variasi $\mathrm{D}$ adalah balok dengan tulangan baja konvensional di bagian tekan dan baja ringan profil $\mathrm{C}$ di bagian tarik.

\section{Tujuan Penelitian}

Adapun tujuan dari penelitian yang penulis lakukan antara lain:

1. Untuk mengetahui pengaruh penggunaan baja ringan sebagai tulangan pada balok beton bertulang terhadap nilai kuat lentur balok.

2. Untuk mengetahui pengaruh penggunaan baja ringan sebagai tulangan pada balok beton bertulang terhadap nilai lendutan balok.

\section{LANDASAN TEORI}

Pada penelitian Andreas (2012), yang berjudul "Studi Eksperimental Balok Komposit Baja Ringan dengan Balok Beton Bertulang", baja ringan Liped Channel pada struktur balok dimanfaatlan pada serat bawah sebagai pengganti tulangan sekaligus digunakan bekisting balok.

Dalam penelitian Oktorin (2014), yang berjudul "Kapasitas Lentur Balok Komposit Beton-Baja Ringan" menggunakan material baja ringan mutu G550, tebal $1 \mathrm{~mm}$ produksi blue scope steel yang dimanfaatkan sebagai cover balok dan bekisting.

Selain itu, penelitian Tambunan (2015), yang berjudul "Studi Eksperimental Kuat Lentur Pada Balok Beton Bertulang Dengan Perkuatan Baja Ringan Profil U di Daerah Tarik" dengan tujuan untuk mengetahui dan membandingkan kapasitas, lendutan serta regangan pada balok beton bertulang dengan atau tanpa perkuatan baja ringan profil $\mathrm{U}$. 
Sedangkan dalam penelitian Hastono (2015), yang berjudul "Penggunaan Baja Ringan/Cold Formed Type Hollow sebagai Tulangan pada Balok Beton Bertulang dalam Memikul Beban Lentur" menggunaan baja ringan tipe hollow sebagai tulangan pada balok beton bertulang.

Pada penelitian Nugroho (2017), yang membandingkan nilai kuat lentur profil $\mathrm{C}$ dari dua perusahaan yang berbeda yaitu PT. Taso dan PT. Baja Pratama. Dari hasil pengujian, dapat disimpulkan bahwa baja ringan dari PT.Taso memiliki nilai kuat lentur yang lebih besar.

Selain itu, penelitian Khodir (2017), yang berjudul "Tinjauan Kinerja Perkuatan Lentur Balok Beton Bertulang dengan Penambahan Baja Ringan" dengan tujuan untuk mengetahui seberapa besar penambahan perkuatan lentur balok beton bertulang ysng dilapisi baja ringan di sisi bawah balok.

Selanjutnya dalam penelitian Tumcala (2018), yang berjudul "Tinjauan Kinerja Balok Beton Bertulang Tampang Empat Persegi Panjang dengan Tulangan dari Baja Ringan" menggunakan baja ringan kanal U sebagai tulangan pada balok beton bertulang.

Sedangkan dalam penelitian Ariyanto (2018), yang berjudul "Tinjauan Kinerja Beton Dengan Pemanfaatan Bahan Pengganti Tulangan Menggunakan Perkuatan Baja Ringan Kanal C" menggunakan baja ringan Kanal C sebagai material untuk menambah perkuatan struktut sebelumnya. Penelitian ini bertujuan untuk mengetahui seberapa besar penambahan perkuatan lentur balok beton bertulang yang dilapisi baja ringan yang tulangannya menggunakan baja ringan.

Menurut Setiawan (2016), beton bertulang merupakan kombinasi dari beton serta tulangan baja, yang bekerja secara bersama-sama untuk memikul beban yang ada. Tulangan baja akan memberikan kuat tarik yang tidak dimiliki oleh beton. Pada suatu struktur beton bertulang dikenal beberapa jenis elemen yang sering digunakan, salah satunya balok. Balok adalah elemen horizontal ataupun miring yang panjang dengan ukuran lebar serta tinggi yang terbatas. Balok berfungsi untuk menyalurkan beban dari pelat.
Baja ringan adalah jenis baja yang terbuat dari logam campuran yang terdiri atas beberapa unsur metal, dibentuk setelah dingin dengan memproses kembali komposisi atom dan molekulnya, sehingga menjadi baja yang lebih ringan dan fleksibel. Berdasarkan Dekoruma (2018), salah satu merk baja ringan yang sangat populer di pasaran adalah baja ringan TASO. Rangka baja ringan TASO mengunakan teknologi terbaru untuk struktur atap yang menerapkan konstruksi baja yang kuat tetapi ringan. Baja ringan TASO terbuat dari bahan atap galvalum, yaitu material baja dengan pelapisan yang mengandung unsur karbon, aluminium dan zinc yang tahan terhadap korosi. Keunggulan dari baja ringan TASO, antara lain: baja ringan TASO anti karat, pemasangannya cukup mudah, biaya untuk baja ringan TASO lebih terjangkau, memiliki bahan yang anti terbakar, anti rayap, tidak mengalami proses pemuaian dan penyusutan, memiliki sifat liat dan daktilitas yang baik.

Profil C merupakan salah satu bentuk profil baja ringan yang terkenal di pasaran. Profil $\mathrm{C}$ sering digunakan sebagai rangka atap pada bangunan. Karena bentuknya yang menyerupai huruf $\mathrm{C}$ seperti pada gambar 1, maka ketika profil ini digabungkan saling berhadapan akan menjadi bentuk kotak sehingga memperkuat rangka satu sama lain.

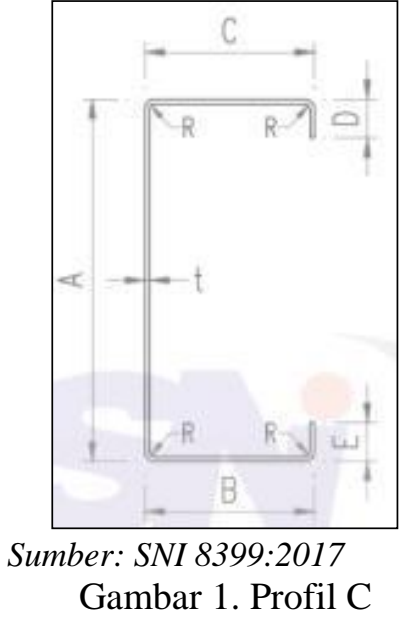

\section{METODE PENELITIAN}

Penelitian ini dilakukan dengan metode eksperimen dan uji laboratorium terhadap bahan campuran beton. 


\section{Jumlah Benda Uji}

Untuk benda uji balok beton bertulang terdapat 12 sampel dengan 4 variasi, masingmasing 3 sampel per variasi dengan dimensi balok $15 \times 15 \times 58 \mathrm{~cm}$. Detail potongan berbagai variasi penulangan pada balok dapat dilihat pada gambar 2. Selain itu, untuk mengontrol nilai kuat tekan beton, dibuat benda uji berupa silinder dengan dimensi $15 \mathrm{x}$ $30 \mathrm{~cm}$ sebanyak 3 sampel. Pengujian kuat tekan beton dan kuat lentur balok dilakukan pada hari ke-28.

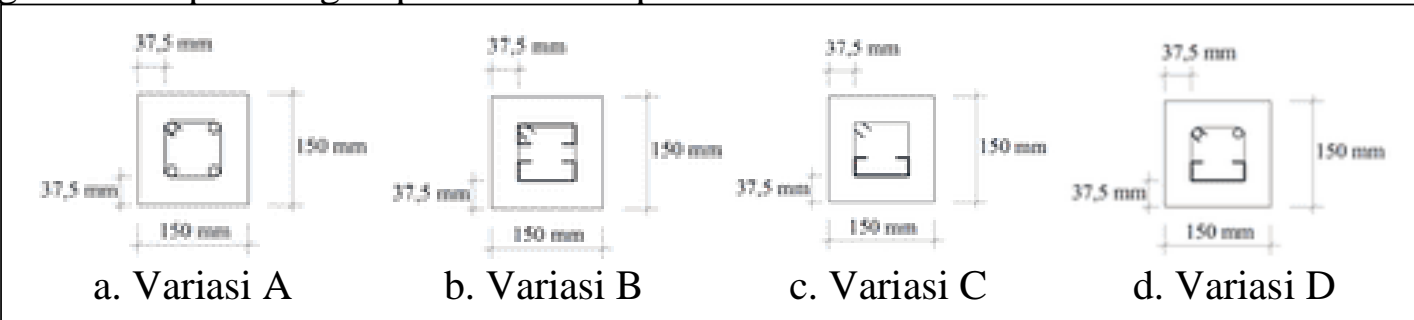

Sumber: Penelitian, 2019

Gambar 2. Detail potongan berbagai variasi penulangan pada balok

\section{HASIL DAN PEMBAHASAN}

\section{Pengujian Kuat Tekan Beton}

Hasil dari pengujian kuat tekan beton disajikan dalam table 1 .

Tabel 1. Hasil pengujian Kuat Tekan Beton

\begin{tabular}{|c|c|c|c|c|c|c|c|c|}
\hline \multicolumn{9}{|c|}{ Kuat tekan rencana $=17 \mathrm{MPa}$} \\
\hline $\begin{array}{l}\text { Kode } \\
\text { benda }\end{array}$ & \multicolumn{2}{|c|}{ Tanggal } & \multirow{2}{*}{$\begin{array}{l}\text { Umur } \\
\text { (hari) }\end{array}$} & \multirow{2}{*}{$\begin{array}{c}\text { Luas } \\
(\mathrm{A}) \\
\left(\mathbf{m m}^{2}\right)\end{array}$} & \multirow{2}{*}{$\begin{array}{c}\text { Berat } \\
(\mathbf{k g})\end{array}$} & \multirow{2}{*}{$\begin{array}{c}\text { Gaya } \\
\text { tekan } \\
(\mathbf{P}) \\
(\mathbf{k N})\end{array}$} & \multirow{2}{*}{$\begin{array}{c}\begin{array}{c}\text { Kuat } \\
\text { tekan } \\
\left(\mathbf{f}_{\mathbf{c}}{ }^{\prime}\right)\end{array} \\
(\mathbf{M P a})\end{array}$} & \multirow{2}{*}{$\begin{array}{c}\begin{array}{c}\text { Kuat } \\
\text { tekan } \\
\text { rata-rata }\end{array} \\
\text { (MPa) } \\
\end{array}$} \\
\hline & Pembuatan & Pengujian & & & & & & \\
\hline S1 & $\begin{array}{c}\text { 05 Desember } \\
2019\end{array}$ & $\begin{array}{l}\text { 02 Januari } \\
2020\end{array}$ & 28 & $17.544,946$ & 12,35 & 290 & 16,529 & \\
\hline S2 & $\begin{array}{c}\text { 05 Desember } \\
2019\end{array}$ & $\begin{array}{l}\text { 02 Januari } \\
2020\end{array}$ & 28 & $17.709,631$ & 12,4 & 300 & 16,940 & 17,078 \\
\hline S3 & $\begin{array}{c}\text { 05 Desember } \\
2019 \\
\end{array}$ & $\begin{array}{l}\text { 02 Januari } \\
2020\end{array}$ & 28 & $17.451,186$ & 12,2 & 310 & 17,764 & \\
\hline
\end{tabular}

Sumber: Hasil Pengujian, 2020

Berdasarkan Tabel 1, diperoleh hasil pengujian ketiga benda uji tersebut dengan nilai rata-rata kuat tekan beton sebesar 17,078 Mpa, dimana nilai tersebut telah mencapai kuat tekan yang direncanakan sebesar $17 \mathrm{MPa}$.

\section{Pengujian Kuat Lentur Beton}

Hasil dari pengujian kuat lentur balok disajikan dalam tabel 2.

Tabel 2. Hasil Pengujian Kuat Lentur Balok

\begin{tabular}{|c|c|c|c|c|c|c|c|}
\hline Variasi & $\mathbf{L}(\mathbf{m})$ & b (m) & h (m) & Berat $(\mathbf{k g})$ & Lendutan izin(mm) & P maks $(\mathrm{N})$ & $\begin{array}{c}\text { Rata-rata P } \\
\text { maks (N) }\end{array}$ \\
\hline A1 & 0,58 & 0,148 & 0,149 & 31,1 & 2,42 & 93.000 & \\
\hline A2 & 0,582 & 0,15 & 0,148 & 31,6 & 1,68 & 85.000 & 90.667 \\
\hline A3 & 0,582 & 0,15 & 0,15 & 31,2 & 2,42 & 94.000 & \\
\hline B1 & 0,584 & 0,145 & 0,15 & 29,8 & 2,42 & 55.000 & \\
\hline B2 & 0,584 & 0,15 & 0,15 & 30,1 & 2,42 & 65.000 & 65.333 \\
\hline B3 & 0,584 & 0,153 & 0,148 & 29,5 & 2,42 & 76.000 & \\
\hline $\mathrm{C} 2$ & 0,582 & 0,148 & 0,15 & 30,5 & 1,72 & 62.000 & \\
\hline C3 & 0,584 & 0,148 & 0,15 & 31,2 & 2,42 & 60.000 & 61.000 \\
\hline D1 & 0,58 & 0,15 & 0,153 & 31,6 & 2,42 & 87.000 & 77.333 \\
\hline
\end{tabular}




\begin{tabular}{|c|c|c|c|c|c|c|c|}
\hline Variasi & $\mathbf{L}(\mathbf{m})$ & b (m) & $\mathbf{h}(\mathbf{m})$ & Berat $(\mathrm{kg})$ & Lendutan izin(mm) & $P$ maks $(\mathrm{N})$ & $\begin{array}{c}\text { Rata-rata P } \\
\text { maks (N) }\end{array}$ \\
\hline D2 & 0,582 & 0,148 & 0,15 & 31,4 & 2,42 & 72.000 & \\
\hline D3 & 0,58 & 0,149 & 0,148 & 30,3 & 2,42 & 73.000 & \\
\hline
\end{tabular}

Sumber: Hasil Pengujian, 2020

Berdasarkan Tabel 2, penggunaan baja ringan sebagai tulangan menghasilkan nilai beban layan yang lebih rendah dari pada beton dengan tulangan baja konvensional (variasi A). Hal ini dikarenakan penggunaan baja ringan pada balok beton bertulang untuk mutu $17 \mathrm{MPa}$ lebih dominan mengalami gagal geser, dimana ketika beton sudah mencapai regangan ultimit sedangkan tulangan belum mencapai batas regangan yang diizinkan. Hal ini terlihat pada saat pengujian, balok beton mengalami keruntuhan secara tiba-tiba dan terjadi didaerah tumpuan.

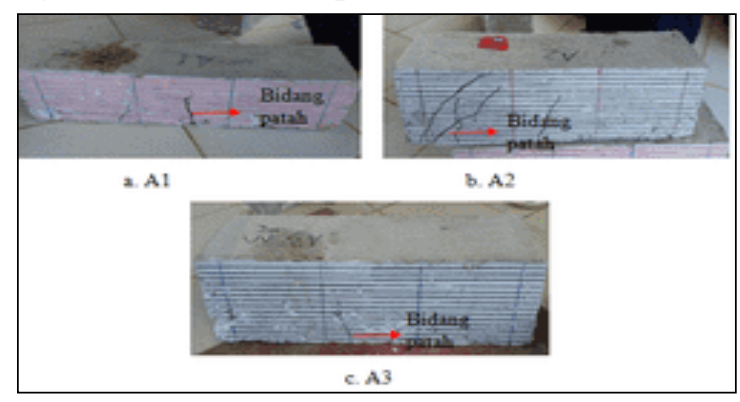

Sumber: Hasil Pengujian, 2020

Gambar 3. Letak bidang patah balok beton variasi A

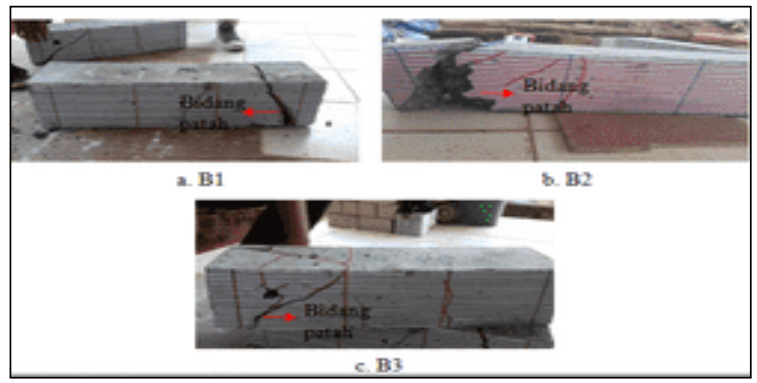

Sumber: Hasil Pengujian, 2020

Gambar 4. Letak bidang patah balok beton variasi B
Dari hasil pengujian kuat lentur balok beton dengan komposisi tulangan yang berbeda, menghasilkan nilai beban layan yang mampu ditahan oleh setiap balok berbeda pula, begitupun dengan letak bidang patah yang dihasilkan seperti pada gambar 3, 4, 5, dan 6. Letak bidang patah seperti pada SNI 4431:2011 pada balok beton menjadi acuan dalam menentukan rumus yang akan digunakan untuk menganalisis nilai kuat lentur pada balok beton. Hasil analisis nilai kuat lentur balok berdasarkan hasil uji disajikan pada tabel 3 .

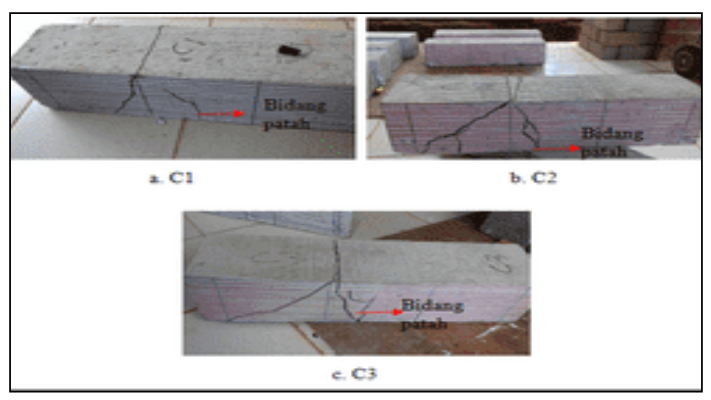

Sumber: Hasil Pengujian, 2020

Gambar 5. Letak bidang patah balok beton variasi C

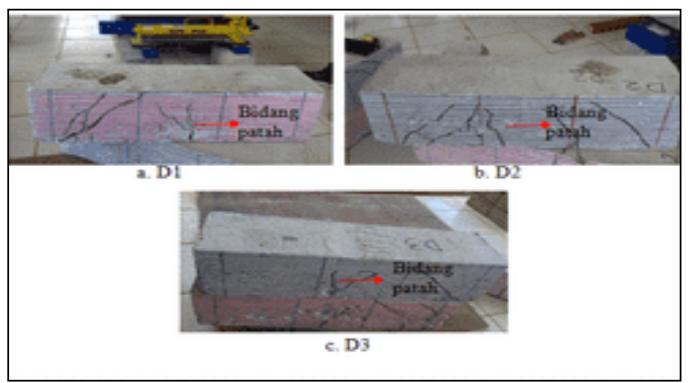

Sumber: Hasil Pengujian, 2020

Gambar 6. Letak bidang patah balok beton variasi D

Tabel 3. Hasil analisis kuat lentur balok berdasarkan hasil uji

\begin{tabular}{ccccccc}
\hline Variasi & $\mathbf{L}(\mathbf{m m})$ & $\mathbf{b}(\mathbf{m m})$ & $\mathbf{h}(\mathbf{m m})$ & P maks (N) Kuat Lentur (MPa) & Rata-rata Kuat Lentur (MPa) \\
\hline A1 & 580 & 148 & 149 & 93.000 & 16,416 & 16,313 \\
A3 & 582 & 150 & 150 & 94.000 & 16,210 & \\
C2 & 582 & 148 & 150 & 62.000 & 10,836 & 10,679 \\
C3 & 584 & 148 & 150 & 60.000 & 10,523 & \\
D1 & 580 & 150 & 153 & 87.000 & 14,371 & 13,309 \\
D2 & 582 & 148 & 150 & 72.000 & 12,584 & \\
D3 & 580 & 149 & 148 & 73.000 & 12,973 & \\
\hline
\end{tabular}

Sumber: Hasil Perhitungan, 2020 
Untuk sampel A2, B1, B2, dan B3 nilai kuat lentur tidak bisa dihitung dikarenakan benda uji tersebut mengalami bidang patah yang terletak diluar pusat (daerah 1/3 jarak titik perletakan bagian tengah) dan jarak antara titik pembebanan dan titik patah lebih dari $5 \%$ bentang. Secara umum, penggunaan baja ringan sebagai tulangan menghasilkan nilai kuat lentur lebih kecil dari pada balok beton dengan tulangan baja konvensional (variasi A). Hal ini dikarenakan nilai kuat lentur berbanding lurus dengan nilai beban layan yang dihasilkan, sedangkan nilai beban layan yang dihasilkan balok beton dengan tulangan baja ringan lebih kecil dari balok beton dengan tulangan baja konvensional (variasi A).

\section{Momen Lentur Balok}

Hasil analisis momen lentur berdasarkan teoritis disajikan pada tabel 4.

Tabel 4. Hasil analisis momen lentur berdasarkan teoritis

\begin{tabular}{ccc}
\hline No. & Variasi & $(\boldsymbol{k N m})$ \\
\hline 1. & $A$ & 3,726 \\
2. & $B$ & 5,46 \\
3. & $C$ & 5,46 \\
4. & $D$ & 6,780 \\
\hline \multicolumn{2}{l}{ Sumber: Hasil Perhitungan, 2020}
\end{tabular}

Sumber: Hasil Perhitungan, 2020
Berdasarkan hasil analisis momen lentur pada tabel 4, dengan adanya penggunaan baja ringan sebagai tulangan pada balok beton bertulang menghasilkan nilai momen lentur lebih besar dari balok beton dengan tulangan baja konvensional (variasi A). Hal ini dikarenakan mutu baja ringan sebesar 550 $\mathrm{MPa}$ lebih besar dari mutu tulangan baja konvensional sebesar $240 \mathrm{MPa}$, sehingga secara kekuatan baja ringan lebih unggul dibandingkan baja konvensional. Selain itu, penggunaan baja ringan sebagai tulangan, menghasilkan distribusi blok tegangan beton tekan yang lebih besar sebesar 28,037 mm untuk variasi $\mathrm{B}$ dan $\mathrm{C}$ dibandingkan dengan balok beton dengan tulangan baja konvensional (variasi A) sebesar 17,313 mm, dimana distribusi blok tegangan digunakan sebagai salah satu parameter dalam perhitungan.

Akan tetapi berdasarkan hasil pengujian yang disajikan pada tabel 5, penggunaan baja ringan sebagai tulangan menghasilkan nilai momen lentur lebih kecil dari balok beton dengan tulangan baja konvensional. Hal ini dikarenakan beban layan yang dihasilkan lebih kecil dari balok beton dengan tulangan baja konvensional (variasi A), dimana nilai momen lentur berbanding lurus dengan nilai beban layan yang dihasilkan.

Tabel 5. Hasil analisis momen lentur balok berdasarkan hasil uji

\begin{tabular}{|c|c|c|c|c|c|c|c|}
\hline Variasi & $\mathbf{L}(\mathbf{m})$ & $\mathbf{b}(\mathbf{m})$ & $\mathbf{h}(\mathbf{m})$ & $q\left(\mathbf{k N} / \mathbf{m}^{\prime}\right)$ & $P$ maks $(\mathbf{k N})$ & $\begin{array}{c}\text { Momen lentur } \\
(\mathrm{kNm})\end{array}$ & $\begin{array}{c}\text { Rata-rata } \\
\text { momen } \\
\text { lentur } \\
(\mathrm{kNm})\end{array}$ \\
\hline A1 & 0,58 & 0,148 & 0,149 & 0,529 & 93 & 13,507 & \multirow{3}{*}{13,199} \\
\hline $\mathrm{A} 2$ & 0,582 & 0,15 & 0,148 & 0,533 & 85 & 12,390 & \\
\hline A3 & 0,582 & 0,15 & 0,15 & 0,540 & 94 & 13,700 & \\
\hline B1 & 0,584 & 0,145 & 0,15 & 0,522 & 55 & 8,052 & \multirow{3}{*}{9,561} \\
\hline B2 & 0,584 & 0,15 & 0,15 & 0,540 & 65 & 9,513 & \\
\hline B3 & 0,584 & 0,153 & 0,148 & 0,543 & 76 & 11,119 & \\
\hline $\mathrm{C} 2$ & 0,582 & 0,148 & 0,15 & 0,533 & 62 & 9,044 & \multirow{2}{*}{8,913} \\
\hline C3 & 0,584 & 0,148 & 0,15 & 0,533 & 60 & 8,783 & \\
\hline D1 & 0,58 & 0,15 & 0,153 & 0,551 & 87 & 12,638 & \multirow{3}{*}{11,248} \\
\hline D2 & 0,582 & 0,148 & 0,15 & 0,533 & 72 & 10,499 & \\
\hline D3 & 0,58 & 0,149 & 0,148 & 0,529 & 73 & 10,607 & \\
\hline
\end{tabular}

Sumber: Hasil Perhitungan, 2020

Dari hasil perhitungan analisis berdasarkan hasil uji dan analisis berdasarkan teoritis diperoleh perbedaan nilai momen lentur yang didapatkan seperti yang tertera pada gambar 7 . 


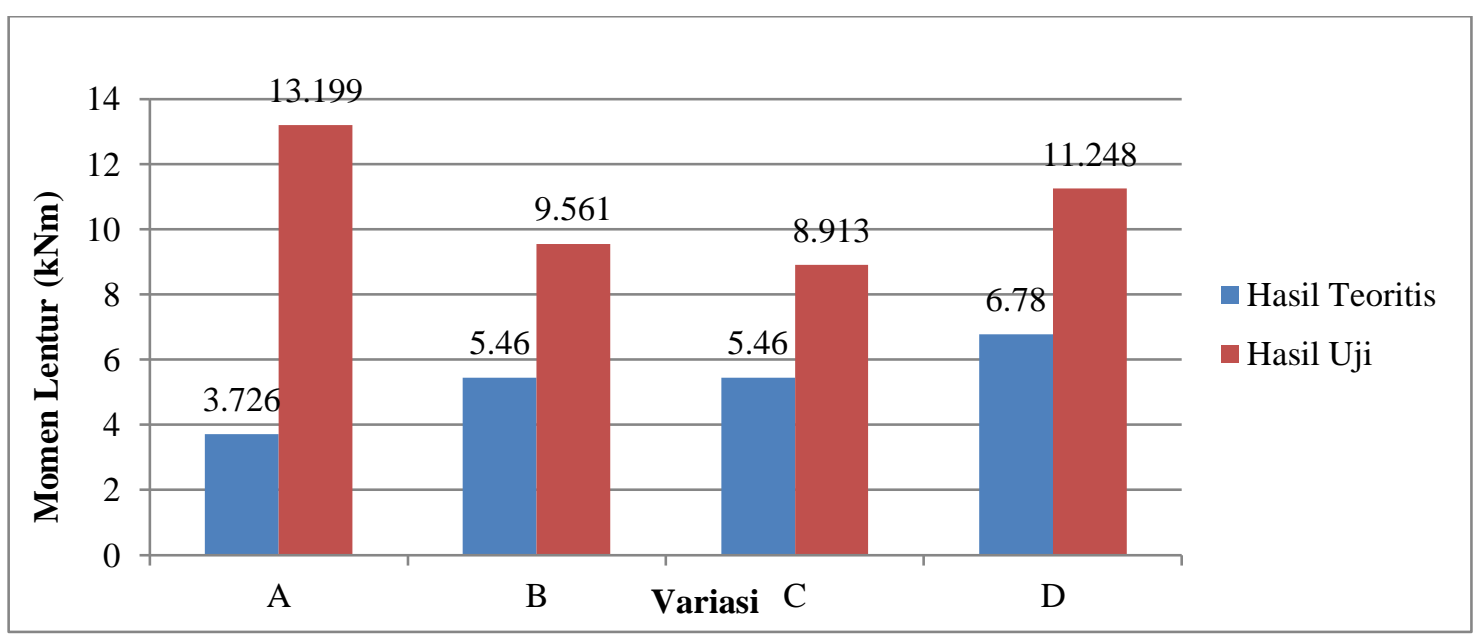

Sumber: Hasil Perhitungan, 2020

Gambar 7. Perbedaan nilai momen lentur berdasarkan hasil uji dan teoritis

Berdasarkan gambar 7, dapat diketahui bahwa nilai momen lentur yang dihasilkan dari hasil uji dan analisis teoritis memiliki perbedaan untuk variasi A sebesar 354,2\%, variasi $\mathrm{B}$ sebesar $175,1 \%$, variasi $\mathrm{C}$ sebesar $163,2 \%$, dan variasi D sebesar $165,9 \%$. Hal ini dikarenakan pada penelitian ini tidak ada pemeriksaan terhadap mutu dari masingmasing tulangan yang kemungkinan mutu aktual dan mutu yang ditetapkan berdasarkan spesifikasi berbeda sehingga menjadi penyebab terjadinya perbedaan hasil yang signifikan. Selain itu, pada analisis teoritis untuk variasi $\mathrm{A}$ dan $\mathrm{B}$ diasumsikan memiliki tulangan tunggal karena $\mathrm{A}_{\mathrm{s}}=\mathrm{A}_{\mathrm{s}}{ }^{\prime}$, sedangkan faktanya memiliki tulangan rangkap yang memiliki kekuatan lebih besar dibandingkan balok dengan tulangan tunggal.

\section{Lendutan Pada Balok Beton Bertulang}

Hasil analisis lendutan berdasarkan teoritis disajikan pada gambar 7 .

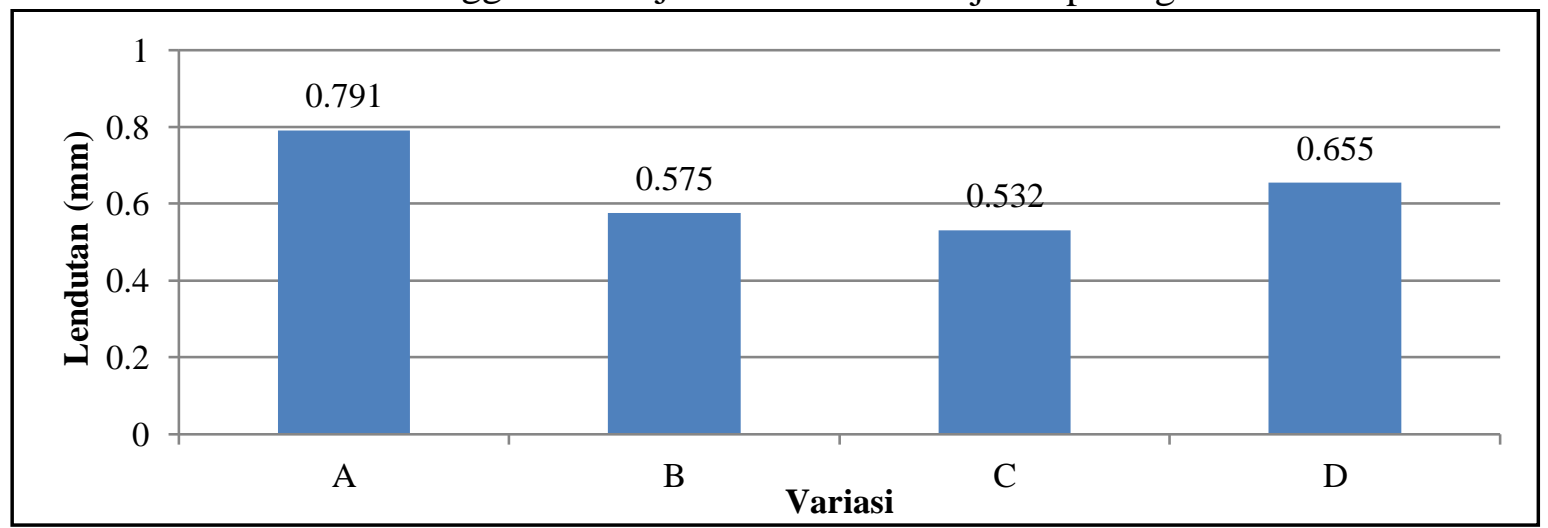

Sumber: Hasil Perhitungan, 2020

Gambar 7. Hasil analisis lendutan berdasarkan teoritis

Berdasarkan gambar 8 , penggunaan baja ringan sebagai tulangan menghasilkan nilai lendutan yang lebih kecil dari balok beton dengan tulangan baja konvensional (variasi A). Hal ini dikarenakan beban layan yang diterima balok dengan tulangan baja ringan lebih kecil dari beban layan yang diterima balok beton dengan tulangan baja, dimana beban layan merupakan salah satu parameter yang digunakan dalam perhitungan. Semakin tinggi nilai beban layan yang dihasilkan, maka semakin besar pula lendutan yang dihasilkan.

\section{KESIMPULAN}

Hasil dari pengujian kuat lentur pada balok beton bertulang dengan dua titik pembebanan adalah sebagai berikut:

1. Pengaruh penggunaan baja ringan sebagai tulangan pada balok beton bertulang 
terhadap nilai kuat lentur balok menghasilkan nilai kuat lentur yang lebih kecil dari pada balok beton dengan tulangan baja konvensional (variasi A), dengan nilai kuat lentur variasi A sebesar $16,313 \mathrm{MPa}$, variasi $\mathrm{C}$ sebesar 10,679 $\mathrm{MPa}$, dan variasi D sebesar 13,309 $\mathrm{MPa}$. Selain itu, berdasarkan analisis teoritis penggunaan baja ringan sebagai tulangan pada balok beton bertulang menghasilkan nilai momen yang lebih besar dari balok beton dengan tulangan baja konvensional (variasi A) dengan nilai momen untuk variasi A sebesar $3,726 \mathrm{kNm}$, variasi $\mathrm{B}$ sebesar 5,460 $\mathrm{kNm}$, variasi $\mathrm{C}$ sebesar $5,460 \mathrm{kNm}$, dan variasi D sebesar 6,780 $\mathrm{kNm}$. Akan tetapi berdasarkan hasil uji, penggunaan baja ringan sebagai tulangan pada balok beton bertulang menghasilkan nilai momen lentur yang lebih kecil dari balok beton dengan tulangan baja konvensional (variasi A) dengan nilai untuk variasi A sebesar 13,199 $\mathrm{kNm}$, variasi B sebesar 9,561 $\mathrm{kNm}$, variasi C sebesar $8,913 \mathrm{kNm}$, dan variasi $\mathrm{D}$ sebesar $11,248 \mathrm{kNm}$. Perbedaan nilai momen lentur yang dihasilkan dari analisis teoritis dan hasil pengujian, dikarenakan pada penelitian ini tidak ada pemeriksaan terhadap mutu dari masing-masing tulangan yang kemungkinan mutu aktual dan mutu yang ditetapkan berdasarkan spesifikasi berbeda sehingga menjadi penyebab terjadinya perbedaan hasil yang signifikan. Selain itu, pada analisis teoritis untuk variasi $A$ dan $B$ diasumsikan memiliki tulangan tunggal karena $\mathrm{A}_{\mathrm{s}}=$ $\mathrm{A}_{\mathrm{s}}{ }^{\prime}$, sedangkan faktanya memiliki tulangan rangkap yang memiliki kekuatan lebih besar dibandingkan balok dengan tulangan tunggal.

2. Pengaruh penggunaan baja ringan sebagai tulangan pada balok beton bertulang terhadap nilai lendutan balok, menghasilkan nilai lendutan yang lebih kecil dari balok beton dengan tulangan baja konvensional (variasi A) berdasarkan analisis teoritis dengan nilai lendutan untuk variasi A sebesar $0,791 \mathrm{~mm}, \mathrm{~B}$ sebesar $0,575 \mathrm{~mm}, C$ sebesar $0,532 \mathrm{~mm}$, dan $\mathrm{D}$ sebesar $0,655 \mathrm{~mm}$. Akan tetapi berdasarkan hasil uji, nilai lendutan balok yang menggunakan baja ringan sebagai tulangan pada balok beton menghasilkan nilai lendutan yang lebih besar dari beton normal dengan nilai untuk variasi $\mathrm{A}$ sebesar 2,173 mm, B sebesar 2,42 mm, C sebesar 2,187 $\mathrm{mm}$ dan D sebesar 2,42 $\mathrm{mm}$. Selisih nilai lendutan yang diperoleh berdasarkan analisis teoritis dan hasil uji untuk variasi A sebesar 274,7\%, B sebesar 420,8\%, C sebesar 411,1\%, dan D sebesar $369,5 \%$.

Untuk penelitian lebih lanjut perlu dilakukan agar dapat menganalisis perilaku balok komposit beton dengan baja ringan, adapun saran yang dapat diberikan adalah sebagai berikut:

1. Jumlah benda uji perlu diperbanyak untuk mendapatkan data yang lebih akurat.

2. Perlu adanya pengujian kuat tarik baja.

\section{UCAPAN TERIMA KASIH}

Pada kesempatan ini, penulis ingin mengucapkan terima kasih kepada seluruh pihak yang telah membantu selama proses penelitian ini. Kepada kedua orang tua beserta keluarga yang telah mendukung penulis, kepada Bapak/Ibu dosen pembimbing yang telah membimbing dan memberi saran dalam penelitian ini serta teman-teman seperjuangan yang telah membantu.

\section{REFERENSI}

Andreas, 2012, Studi Eksperimental Balok Komposit Baja Ringan dengan Balok Beton Bertulang, Jurnal Rekayasa Teknik Sipil, Volume 3, No. 1, hal 149157, http//:scholar.google.co.id, (Diakses pada tanggal 17 Maret 2019).

Ariyanto, A., 2018, Tinjauan Kinerja Beton Dengan Pemanfaatan Bahan Pengganti Tulangan Menggunakan Perkuatan Baja Ringan Kanal $C$, http//:eprints.ums.ac.id, (Diakses pada tanggal 15 Agustus 2019).

Badan Standar Nasional, 2011, SNI 4431:2011 Cara Uji Kuat Lentur Beton Normal 
Dengan Dua Titik Pembebanan, BSN, Jakarta

Badan Standar Nasional, 2017, SNI 8399:2017 Profil Rangka Baja Ringan, BSN, Jakarta.

Dekoruma, 2018, Apa Itu Baja Ringan Taso? Yuk Ketahui Kelebihannya!, https://www.dekoruma.com, (Diakses pada tanggal 16 Juni 2019).

Hastono, K.B., 2015, Penggunaan Baja Ringan/Cold Formed Type Hollow sebagai Tulangan pada Balok Beton Bertulang dalam Memikul Beban Lentur, http//:repository.unitomo.ac.id, (Diakses pada tanggal 21 Maret 2019).

Khodir, M.L., 2017, Tinjauan Kinerja Perkuatan Lentur Balok Beton Bertulang Dengan Penambahan Baja Ringan, $\quad \mathrm{http} / /$ :eprints.ums.ac.id, (Diakses pada tanggal 14 Agustus 2019).

Nugroho, R.Y.A., 2017, Analisis Kuat Lentur Profil C Baja Ringan Sebagai
Komponen Rangka Atap, http//:eprints.ums.ac.id, (Diakses pada tanggal 15 Agustus 2019).

Oktorin, L.A., 2014, Kapasitas Lentur Balok Komposit Beton-Baja Ringan, $\mathrm{http} / /$ :etd.repository.ugm.ac.id, (Diakses pada tanggal 21 Maret 2019).

Setiawan, A., 2016, Perancangan Struktur Beton Bertulang (Berdasarkan SNI 2847:2013), Penerbit Erlangga, Jakarta.

Tambunan, A.M., 2015, Studi Eksperimental Kuat Lentur Pada Balok Beton Bertulang Dengan Perkuatan Baja Ringan Profil $U$ di Daerah Tarik, http//:repository.usu.ac.id, (Diakses pada tanggal 14 Agustus 2019).

Tumcala, A.H., 2018, Tinjauan Kinerja Balok Beton Bertulang Tampang Empat Persegi Panjang dengan Tulangan dari Baja Ringan, http//:eprints.ums.ac.id, (Diakses pada tanggal 17 Maret 2019). 